\title{
THE ROLE OF UNITED NATIONS GENERAL ASSEMBLY RESOLUTIONS IN DETERMINING PRINCIPLES OF INTERNATIONAL LAW IN UNITED STATES COURTS
}

Traditionally, United States courts have not considered United Nations General Assenibly Resolutions to be authoritative sources of imternational law, unless the Resolution merely restated legal principles that could be verified by reference to recognized sources such as customary international law, treaties, and judicial decisions. Recently, however, some courts have gone further and have given General Assembly Resolutions the samè weight as full-fledged sources of international law.' Other courts have refused to take this step and have preferred to treat Resolutions as mere evidence of international law. ${ }^{2}$ As hitigants invoke imternational legal principles with increasing frequency in cases before United States courts, the courts will have to decide whether General Assembly Resolutions can constitute authoritative sources of international law.

Beginning with a background summary of the traditional attitude toward United Nations General Assembly Resolutions as nonbimding recommendations reflecting idealized international legal principles, this note reviews the few United States cases in which courts have used the traditional analysis. ${ }^{3}$ The note then discusses two major decisions, one by an international arbitrator and the other by the United States Court of Appeals for the Second Circuit, that advocate a new role for General Assembly Resolutions as full-fledged sources of international law. ${ }^{4}$ The note describes the hesitant reaction of courts in the United States to this departure from tradition and discusses the policy reasons both for abandoning ${ }^{5}$ and for preserving ${ }^{6}$ the traditional, limited role of General Assembly Resolutions. The note concludes that, although the Resolutions serve as valuable hortatory evidence of emerging legal

1. See infra notes $35-58$ and accompanying text.

2. See infra notes $72-77$ and accompanying text.

3. See infra netes 28-34 and accompanying text.

4. See infra notes $35-58$ and accompanying text.

5. See infra notes $78-89$ and accompanying text.

6. See infra notes 90-116 and accompanying text. 
principles, they should not constitute independent, authoritative sources of international law.

\section{Sources of InTernational Law - The Traditional View}

International law7 governs dealings between sovereign nations, which have historically exercised their powers to avoid becoming bound without their consent. ${ }^{8}$ To give effective consent, nations must know what constitutes consent, that is, what action or inaction on their part will create a binding principle of law. Thus, when a court analyzes an international legal dispute, it begins with the sources of international law by examining the established methods for creating binding legal principles. 9

Four commonly recognized sources of international law have developed over the centuries from interactions between nations. The most widely recognized source is custoin: principles that have developed spontaneously over many years to govern certain recurring international disputes. Courts usually ascertain custom by engaging in a detailed historical analysis of many centuries of state practice, ${ }^{10}$ recognizing a customary legal principle when it reflects both a state's uniform practice over a long period of time and conscious acceptance of the principle as law." Custoin is a reliable source because, by defini-

7. Professor Myres McDougal has underscored the practical importance of knowing what is , and is not a valid source of international lawr: sources of international law present "not merely a theoretical problem, but in actuality a very practical problem. The first question any operating lawyer would want to know was, 'Who is going to decide iny case?'; the second question which would naturally follow would be, 'Who is making the law?' These were not just theoretical inquiries. Legal norms did not simply exist; they were manifested in a continuous process of evolution and hence emanated from several different sources." Summary of Discussion, 73 PROC. OF THE AM. SOC'Y OF INT'L L. 327, 327-28 (1979).

8. Cf. Restatement (REvised) of the Foreign Relations Law of the United States, Introductory Note at 15 (Tent. Draft No. 1, 1980) (importance of unanimous acceptance of rules of international law, rather than merely consent of the majority). See generally L. HENKIN, R. PUgh, O. SCHACuter \& H. SMTt, INTERNATIONAL LAW CASES AND MATERIALS 1-9 (1980)(modern law of nations is intimately connected with the era when sovereign national states dealt with each other as independent units).

9. In The Paguete Habana, 175 U.S. 677 (1900), the Supreme Court of the United States demonstrated the classical method for ascertaining international legal principles by analyzing several centuries of interactions between individnal nations.

10. See, eg., G. Schwarzenderger \& E Brown, A Manual of International Law 2627 (6th ed. 1976)(describing how customary principles are ascertained); see also The Paguete Habana, 175 U.S. at 686-708 (reviewing five centuries of historical practice before concluding that customary international law dictates that fishing vessels are exempt froin capture as prizes of war).

11. The United States Supreme Court used such an analysis in The Paquete Mabana, 175 U.S. $677,700(1900)$. 
tion, a custom only exists if it is consistent with state practice. ${ }^{12}$ Custom leaves much to be desired, however, because historical analysis often leaves unresolved many legal details.

Treaties provide the second commonly used source of international legal principles. ${ }^{13}$ Because a treaty bimds nations that have ratified it, each nation, by its ratification, demonstrates its acceptance of the legal principle embodied in the treaty. Thus, treaties serve as clear indicators of the law.

Other commonly recognized sources include judicial decisions and the teachings of "publicists"-scholars who have written treatises on "public" international law. ${ }^{14}$ The category described as "general principles of law recognized by civilized nations" is also usually included in lists of sources. ${ }^{15}$ This latter category generally includes legal concepts common to unost domestic legal systems and serves an interstitial role, filling the gaps left by treaty and customn. ${ }^{16}$ Principles such as res judicata, pacta sunt servanda (parties must observe their agreements), and

12. See Arangio-Ruiz, The Normative Role of the General Assembly of the Uniled Nations and the Declaration of Principles of Friendly Relations, 137 RECUEIL DEs Cours 419, 482 (1972-111) (describing the elements of the two-part test for custom); accord RESTATEMENT (REVISED) OF THE Foreign Relations LaW of THE United States \& 102(2), \& 102(2) comments b, c, reporter's note 2 (Tent. Draft No. 1, 1980). These authorities expand on the language defining international custom from the Statute of the International Court of Justice, June 26, 1945, art. 38, 59 Stat. 1055, 1060, T.S. No. 993.

13. The Restatement lists customary law and treaties as the two principal sources of international law. See REstatement (ReVISED) OF THE Foreion Relations LAW OF THE UNITED States Introductory Note at 16 (Tent. Draft No. 1, 1980).

14. See Statute of the International Court of Justice, art. 38, 59 Stat. 1055, 1060, T.S. No. 993 (listing judicial decisions and the teachings of publicists as sources of international law).

15. The phrase "general principles of law recognized by civilized nations" is from the Statute of the International Court of Justice, art. 38, 59 Stat. 1055, 1060, T.S. No. 993. The "general principles" category is usually read narrowly. See generally Virally, The Sources of International Law in MANUAL OF Public InTERnational Law 143-48 (M. Sorensen ed. 1968)(explaining current interpretations of this peculiar category). The Restatement continues to list "general principles" as a separate source of international law. See RESTATEMENT (REVISED) OF THE Foreign Relations law of the United States \& 102(4) (Tent. Draft No. 1, 1980). The drafters of the Restatement, however, considered "general principles" to be an independent source of law, separate from custom, only when there has not yet been practice by states sufficient to give a particular principle status as customary law and it has not been legislated by general international agreement. See id. comment 1 . For example they thought general principles might be helpful in determining questions of laches, res judicata, estoppel, or rules of fair procedure. See id.

"General principles" are not meant to serve as a shortcut to custom; however, some authors consider the "general principles" category as almost redundant in light of custom. Sce, e.g., Joyner, U.N. General Assembly Resolutions and International Law: Rethinking the Contemporary Dynamics of Norm-Creation, 11 CAL. W. INT'L L.J. 445, 459-60 (1981)("general principles" are actually just norms consolidated out of customary practice).

16. See supra note 15. 
jurisdictional rules can derive from this source. ${ }^{17}$

Traditional doctrine, developed before the creation of international organizations, naturally does not consider the United Nations' potential role in creating international legal principles. When the United Nations was founded in 1945, member nations codified the traditional doctrine for sources of international law when they drafted the statute governing the authority of the International Court of Justice (ICJ). ${ }^{18}$ The nations did not intend, however, to expand the traditional sources to include General Assembly Resolutions. The drafters of the ICJ Statute rejected a proposal that the Assembly be vested with legislative authority to enact rules of international law. The Philippimes proposed such a role for the General Assembly at the San Francisco Conference in 1945, but the parties to the conference voted it down by an overwhelming margin, ${ }^{19}$ granting the Assembly only the power to recommend and advise. ${ }^{20}$

17. Accord Restatement (Revised) of the Foreign Relations Law of the United STATES (Tent. Draft No. 1,1980$) \& 102$ comment $l$.

18. See Statute of the International Court of Justice, art. 38, 59 Stat. 1055, 1060, T.S. No. 993. The UN Charter, article 93, incorporates the ICJ Statute and makes every UN member nation a party to the treaty establishing the International Court of Justice.

19. See Arangio-Ruiz, supra note 12 , at $446-47$ ("[]] so far as the letter of the Charter is concerned . . . while it would be simply naive to look for a provision spelling out the non-binding character of unqualified General Assembly Resolutions, the relevant Articles do all that is necessary-short of spelling it out in as many words-to exclude the binding character of such resolutions."); see also J. Castaneda, Legal EfFects of UNIted Nattons Resolutions 2-3, 197 n.2 (1969)(the drafters of the ICJ Statute knew very well that within the system of the new United Nations Charter, General Assembly Resolutions would not be bimding); RESTATEMENT (REvisED) of the Foreign Relations Law of the UNITEd STATES \& 103 reporter's note (Tent. Draft No. 1, 1980).

20. See U.N. ChARTER art. 10-14. Arangio-Ruiz writes: "The language of the relevant Articles of Chapter IV of the Charter (Articles 10-14) is far clearer than some international lawyers seem ready to admit, in the sense that the general powers granted to the Assembly under those Articles do not involve binding decision-making except where it is specially so provided expressly or by implication." Arangio-Ruiz, supra note 12, at 445; cf. Schwebel, The Effect of Resolutions of the U.N. General's ssembly on Customary International Law, 73 PROC. OF THE AM. SOC'Y OF INT'L L. 301, 301 (1979) (potentially unfair effects of one-state, one-vote procedure were balanced by giving the General Assembly only recommendatory powers). But see J. Castaneda, supra note 19, at 8 (U.N. Charter language is equivocal-reasonable doubt exists whether recommendation can have legal effect).

The official Soviet position is that General Assembly Resolutions bear only recommendatory character and cannot create legal obligations for nember states. See G. TUNKIN, THEORY OF International LAw 170-71 (1974). Professor Higgins also considers Article 2(7) of the UN Charter to be a clause that constrains the General Assembly from exceeding its recommendatory powers when analyzing international law principles. See generally R. Higgins, The DevelopMENT OF INTERNATIONAL LAW THROUGH THE POLITICAL ORGANS OF THE UNITED NATIONS 58- 130 (1963). Article 2(7) forbids member states from intervening in matters that are essentially within the domestic jurisdiction of any state. See U.N. CHARTER art. 2(7). 
Since 1945, the role of the United Nations has grown dramatically, and the General Assembly has emerged as a forum for international dialogue. The General Asseinbly has adopted many Resolutions concerning international legal principles that meinbers of the Assembly hoped would serve as normative standards. These declaratory Resolutions cover a wide variety of subjects such as women's rights, ${ }^{21}$ the right to be free from torture, ${ }^{22}$ the right of all people to self-determination, ${ }^{23}$ the rights and duties of nations who expropriate foreign-owned assets ${ }^{24}$ and other controversial issues. ${ }^{25}$ Resolutions thus address many sensitive areas in which custom, treaties, and other fornal sources provide hittle guidance about what the international law is. ${ }^{26}$

\section{United States Courts' Treatment of General Assembly RESQLUTIONS}

Umited States courts hear very few eases that turn on principles of international law. The few cases that have arisen since 1945 have occasionally referred to General Asseinbly Resolutions to support their conclusions. ${ }^{27}$ Whether United States courts are willing to accord significant weight to UN General Asseinbly Resolutions as legal sourccs, however, remains unclear.

21. See, eg., Declaration on Elimination of Discrimination Against Women, G.A. Res. 2263, 22 U.N. GAOR Supp. (No. 16) at 35, U.N. Doc. A/6716 (1967).

22. See, eg., Universal Declaration of Human Rights, G.A. Res. 217, 3 U.N. GAOR, U.N. Doc. A/777 (1948).

23. See, eg., Declaration on the Granting of Independence to Colonial Countries and Pcoples, G.A. Res. 1514, 15 U.N. GAOR Supp. (No. 16) at 66, U.N. Doc. A/4684 (1960).

24. See, eg., Declaration.on the Establishment of a New International Economic Order, G.A. Res. 3201, Sixth Spec. Sess. U.N. GAOR Supp. (No. 1) at 3, U.N. Doc. A/9559 (1974).

25. See, eg., Declaration on Principles of International Law Concerning Friendly Relations and Cooperation Among States in Accordance with the Charter of the United Nations, G.A. Res. 2625, 25 U.N. GAOR Supp. (No. 28) at 121, U.N. Doc. A/8028 (1970); Declaration on the Prohibition of the Use of Nuclear and Thermo-Nuclear Weapons, G.A Res. 1653, 16 U.N. GAOR Supp. (No. 17) at 4, U.N. Doc. A/5100, (1961).

26. The Restatement distinguishes between "sources" and "evidence" of international law. See Restitement (Revised) OF tHe Foreign Relations Law of tHe UnIted States 88 102, 103 (Tent. Draft No. 1, 1980). Certainly, General Assembly Resolutions "may stimulate action towards, or provide an incipient step for the genesis of customary international law." Joyner, supra note 15, at.459. Resolutions may happen to contain principles of international law that independently meet the criteria for custom. Resolutions may even serve as part (but never all) of the evidence that convinces a court that nations have created a principle of customary international law through their acceptance and practice. But, according to traditional theory, Resolutions are never custom in and of themselves. Resolutions "are capable, like many other things, of contributing to the formation of rules of lex communis, and can in that sense constitute material influencing the content of the law, but not creating it" Fitzmaurice, The Future of Public International Law and of the Intemational Legal System in the Circumstances of Today, LIVRE DU CentenalRe, 1873-1973 196, 269 (1973)(emphasis in original).

27. See infra text accompanying notes 28-77. 


\section{A. The Early Cases.}

Before 1977, the few United States courts that addressed whether UN General Assembly Resolutions should serve as authoritative sources of international law largely followed the traditional view that they should not. The courts did not formally discuss the merits of General Assembly Resolutions, but simply declined to give Resolutions any weight.

For example, in Diggs $v$. Dent, ${ }^{28}$ a federal district court faced the question whether several United Nations Resolutions related to South Africa's "illegal" occupation of Namibia were enforceable. ${ }^{29}$ Instead of trying to decide the case on the merits, the court held that it lacked subject matter jurisdiction to hear the case, ${ }^{30}$ thus successfully sidestepping the issue. In Diggs $v$. Richardson, ${ }^{31}$ a similar case involving the United States' relations with South Africa, the Court of Appeals for the District of Columbia Circuit held that a claim based on UN Security Council Resolutions ${ }^{32}$ was nonjusticiable, declining to decide whether a Security Council Resolution can create an enforceable international obligation..$^{33}$

In these early cases the courts emphasized that United Nations enactments under the UN charter, such as UN Security Council Resolutions and the UN Charter itself, are not self-executing and thus are not

28. 14 Int'L LeGal MATERIALS 797 (D.D.C. 1975).

29. See id. The plaintiff claimed that "United Nations Resolutions are positive domestic law and as such are judicially enforceable." Id. at 803.

30. Id. at 804-05. The court revealed in dictum that it would have considered the issue nonjusticiable even if it had had jurisdiction because it was reluctant to infringe on the executive branch's power to manage foreign affairs. Id.

31. 555 F.2d 848 (D.C. Cir. 1976).

32. Security Council Resolutions are thcoretically binding on UN member states. Article 25 of the United Nations Charter provides: "The members of the United Nations agree to accept and carry out the decisions of the Security Council in accordance with the present Charter." U.N. CHARTER art. 25. Thus, Diggs v. Richardson, 555 F.2d 848 (D.C. Cir. 1976), might have been an appropriate case for a United States court to defer to a UN Resolution in order to honor the United States' treaty obligation arising from the UN Charter. But see infra note 33.

33. Richardson, 555 F.2d at 850 . In case there was any doubt about which authority governed when there was a clash between Security Council Resolutions and Acts of Congress, the Court of Appeals for the District of Columbia Circuit, in Diggs v. Schultz, 470 F.2d 461, 465 (D.C. Cir. 1972), cert. denied, 411 U.S. 931 (1973), held that Congress was not bound to follow a Security Council Resolution even though the Resolution took its binding authority directly from the United Nations Charter (a treaty to which the United States is a party). According to the Schuliz court, Congress could abrogate part of its treaty commitment under the United Nations Charter and not violate any United States coustitutional provisions. Such an action would still constitute a - breach of treaty obligation under international law, for which the United States as a nation would be liable. The Schulzz court did not discuss this issue, however. 
binding on a court in the absence of implementing legislation. ${ }^{34} \mathrm{Al}-$ though these courts did not address whether General Asseinbly Resolutions bind the states that were party to the enactments, the Dent and Richardson holdings suggest that most United States courts prefer to rely on a definitive acceptance of the international principle by a doinestic organ such as Congress or the President.

34. See United States v. Vargas, 370 F. Supp. 908, 915 (D.P.R. 1974), rev'd on other grounds, 558 F.2d 631 (1st Cir. 1977) (UN Charter invoked). Moreover, courts have suggested that such enactments do not in themselves vest individual rights in United States litigants. In SanchezEspinoza v. Reagan, 568 F. Supp. 596, 598, 601 n.6 (D.D.C. 1983) the court granted a motion to dismiss a claim by Nicaraguan plaintiffs seeking damages for "U.S.-sponsored terrorist raids" against various Nicaraguan towns. Plaintiffs claimed the raids violated fundamental hunan rights established under international law and the United States Constitution, citing as authority numerous Resolutions and treaties including the UN Charter, 59 Stat. 1033 (1945), the Universal Declaration of Human Rights, G.A. Res. 217, 3 U.N. GAOR, U.N. Doc. A/777 (1948), G.A. Res. 191, U.N. Doc. A/64/Add. 1 at 188 (1964), the Declaration of Principles of International Law Concerning Friendly Relations and Cooperation Among States, G.A. Res. 2625, 25 U.N. GAOR Supp. (No. 28) at 121, U.N. Doc. A/8028 (1970), and the Declaration on the Protection of All Persons Fron Being Subjected to Torture, G.A. Res. 3452, 30 U.N. GAOR Supp. (No. 34) at 91, U.N. Doc. A/10034 (1975). The court said: "Because we dismiss this lawsuit as nonjusticiable, we do not decide whether any or all of those sources of international law create a legal foundation for the relief requested by plaintiffs. Compare Filartiga v. Pena-Irala, 630 F.2d 876 (2d Cir. 1980) (torture is a violation of the law of nations that gives rise to an action for damages in federal court) with Hanoch Tel-Oren v. Libyan Arab Republic, 517 F. Supp. 542 (D.D.C. 1981) (law of nations or treaties nuist provide for private rights of action in order for an injured plaintiff to obtain relief in federal court under alien tort statute, 28 U.S.C. \& 1350)." See also Diggs v. Richardson, 555 F.2d 848, 850 (D.C. Cir. 1976) (Security Council Resolution invoked); Diggs v. Dent, 14 INT'L LEGAL MATERIALS 797, 804 (D.D.C. 1975)(UN Charter invoked); $c$. Dreyfus v. Von Finck, 534 F.2d 24, 31 (2d. Cir.), cert. denied, 429 U.S. 835 (1976) ("law of nations" invoked).

Consider, for example, Judge Friendly's reluctance to recognize as international law one of the fundamental proscriptions of the Ten Coromandments. "The reference to the law of nations must be narrowly read if the section [28 U.S.C. \& 1350] is to be kept within the confines of Article' III. We cannot subscribe to plaintiffs' view that the Eighth Commandinent 'Thou shalt not steal' is part of the law of nations." ITT v. Vencap Ltd., 519 F.2d 1001, 1015 (2d. Cir. 1975).

Judge Friendly explained that "[w]hile every civilized nation doubtless has this [the equivalent of the Eighth Conmandment] as a part of its legal system, a violation of the law of nations arises only when there has been 'a violation by one or more individuals of those standards, rules or customs (a) affecting the relationship between states or between an individual and a foreign state, and (b) used by those states for their common good and/or in dealings inter se." "Id. at I015 (quoting Lopes v. Reederei Richard Schroder, 225 F. Supp. 292 (E.D. Pa. 1963)). If United States courts subscribe to this view, there would be very few cases when a General Assembly Resolution wonld have any application in a domestic court, no matter how binding the Resolution under principles of international law.

Undoubtedly, Judge Friendly was concerned that some sovereign nations might take exception even to such a fundamental principle as the Eighth Commandment. Given the recent tendency of soune countries to expropriate foreign-owned assets within their borders, perhaps Judge Friendly's solicitude for the rights of other sovereign nations was not as misplaced as it might otherwise appear. 


\section{B. The Texaco Overseas Arbitration and the Filartiga Decision.}

A forceful international arbitration in 1977 prompted United States courts to address more directly the use of General Assembly Resolutions. In Texaco Overseas Petroleum Co. v. Libyan Arab Republic, ${ }^{35}$ arbitrator Rene Dupuy, a noted French jurist, tried to determine what the appropriate standard of compensation should be under international law ${ }^{36}$ when a country expropriates foreign-owned assets.

Several General Assembly Resolutions legitimize expropriation and set a standard for compensation. ${ }^{37}$ Professor Dupuy decided that any Resolution commanding the support of "a majority of member States representing all of the various groups" could serve as a basis for settling the dispute. ${ }^{38}$ After engaging in a detailed analysis of the circumstances surrounding various Resolutions, Professor Dupuy concluded that General Assembly Resolution 1803 (XVII), which mandates "appropriate compensation," commanded the necessary snpport. ${ }^{39}$ Professor Dupuy's analysis of various Resolutions is renarkably similar to the process that a court would use to ascertain customary international law. The important difference, however, is that Dupuy was examining each country's behavior in the controlled environment of the United Nations instead of customary behavior in the larger world arena.40 Thus, even though Dupuy drew on the principles of

35. 17 INT'L Legal Materials 1 (1978).

36. The parties stipulated that international law would govern the dispute. Id at 9.

37. See, e.g., Charter of Economic Rights and Duties of States, G.A. Res. 3281 (XXIX), 29 U.N. GAOR Supp. (No. 31) at 50, U.N. Doc. A/9631 (1974) (120 nations voted in favor; six voted against; ten abstained including the United States, West Germany and Great Britain); Declaration on the Establishment of a New International Economic Order, G.A. Res. 3201 (S. VI), Sixth Spec. Sess. U.N. GAOR Supp. (No. 1 ) at 3, U.N. Doc. A/9559 (1974)(adopted without a vote); Permanent Sovereignty over Natural Resources, G.A. Res. 3171 (XXVII), 28 U.N. GAOR Supp. (No. 30) at S2, U.N. Doc. A/9030 (1973) (108 nations voted in favor; one voted against (Great Britain); 16 abstained including the United States, France, West Germany, and Japan); Permanent Sovereignty over Natural Resources, G.A. Res. 1803 (XVI), 17 U.N. GAOR Supp. (No. 17) at 15, U.N. Doc. A/5217 (1962) (87 nations voted in favor; two voted against (France and South Africa); twelve Soviet Bloc nations abstained).

38. See 17 INT'L LEgal MATERIals at 30.

39. Id.

40. Professor Dupuy held that "the legal value of the resolutions which are relevant to the present case can be determined on the basis of circumstances under which they were adopted and by analysis of the principles which they state." Id. Although he had just conceded that "the legal value of the declaratory resolutions . . . includes an immense gamut of nuances," " Professor Dupuy asserted that Resolutions, "which proclaim rules recognized by the community of nations . . . do not create a custom but confirm one by formulating it and specifying its scope, thereby making it possible to determine whether or not one is confronted with a legal rule." Id. at 29-30 (quoting La Valeur des Resolutions des Nations Unies, 129 R.C.A.D.1. 204, 319-20 (1970)). Therefore, Professor Dupuy concluded that:

on the oceasion of the vote on a resolution finding the existence of a customary rule, the States concerned clearly express their views. The consensus by a inajority of states be- 
custom, he departed significantly from the traditional analysis. ${ }^{41}$

In 1980, three years after Texaco Overseas, the United States Court of Appeals for the Second Circuit, in Filartiga v. Pena-Irala, ${ }^{42}$ also accorded significant weight to UN General Assembly Resolutions. In Filartiga, a Paraguayan family whose son had been tortured and killed by officials in Paraguay brought a wrongful death action against one of the alleged torturers while he was visiting the United States. To obtain jurisdiction under the Alien Tort Claims Act, the court had to find that torture was a violation of international law. ${ }^{43}$

The Filartiga court twice suggested that it was using traditional custom analysis. ${ }^{44}$ The court stated that, "although there is no universal agreement as to the precise extent of the 'human rights and fundainental freedoms' guaranteed to all [persons] by the [United Nations]. Charter, there is at present no dissent from the view that the guaranties inciude, at a bare minimum, the right to be free from torture."45 The court briefly discussed a host of General Assembly Resolutions, treaties, case decisions, legal essays, and affidavits of international law scholars to prove that no country claims the right to torture its citizens. ${ }^{46}$

The court punctuated its discussion with comments that indirectly suggest it considered General Asseinbly Resolutions to be authoritative sources of international law. For example, the court stated that the Umited Nations Charter precepts embodied in the Universal Declara-

\footnotetext{
longing to the various representative groups indicates without the slightest doubt universal recognition of the rules therein incorporated. Id at 30.

41. Professor Dupuy's analysis is built on an argument made eleven years earlier by Judge Tanaka of the International Court of Justice. In a dissenting opinion to the South West Africa Coses (Ethiopia v. S. Afr.), 1966 I.C.J. 248, 291-93 (Second Pliase), Judge Tanaka argued that when one is trying to prove that a certain customary norm of international law exists, General Assembly Resolutions can be used as evidence of general practice. Id at 291. Judge Tanaka suggested that the General Assembly can accelerate the formation of customary law by serving as a forum in which a state "has the opportunity, through the medium of the organization, to declare its position to all members of the organization and to know immediately their reaction on the same matter." Id.

Judge Tanaka hoped that by reference to United Nations activities custonary primciples could becoune established in "one generation or even far less than that." Id. Judge Tanaka was nonetheless cautious not to stray too far from the traditional doctrine. He carefully noted that individual resolutions and declarations cannos have binding force on unember nations. Id. at 292. To say that General Assembly Resolutions can serve as evidence of incipient custom strains tradition much less than to say such Resolutions constitute autonounous sources of international law. Judge Tanaka chose the former view; Professor Dupuy would probably choose the latter.

42. 630 F.2d 876 (2d Cir. 1980).

43. Id at 880 .

44. See id at 881, 884; see also infra note 57.

45. Id. at 882 (einphasis added).

46. Id at $880-85$.
} 
tion of Human Rights, General Assembly Resolution 217 (III)(A), ${ }^{47}$ "constitute basic principles of international law." "48 To support this point, the court cited General Assembly Resolution 2625 (XXV), 49 and noted that the Declaration on the Protection of All Persons from Being Subjected to Torture, General Assembly Resolution 3452,50 was adopted without dissent. . $^{\text {S1 }}$

The court also referred to a memorandum from the United $\mathrm{Na}$ tions Secretariat's Office of Legal Affairs suggesting that General Asseinbly Declarations are formal and solemn instruments suitable for rare occasions when primciples of great and lasting importance are enunciated.52 The court then returned to the Universal Declaration of Human Rights, stating that this Resolution "no longer fits into the dichotomy of 'binding treaty' against 'nonbinding pronouncement,' but is rather an authoritative statement of the imternational commumity."s3 Finally, the court cited several "treaties and accords" as proof of the international consensus against torture, including the International Covenant on Civil and Political Rights, General Asseınbly Resolution $2200(\mathrm{XXI})(\mathrm{A}),{ }^{54}$ and concluded that these enactments proved that tor-

47. G.A. Res. 217 (III)(A), 3 U.N. GAOR, U.N. Doc. A/777 (1948).

48. Filartiga, 630 F.2d at 882 (quoting G.A. Res. 2625).

The Filartiga court's words can also be construed as a fleeting reference to "general principles of law recognized by civilized nations," an authoritative source of international law different from custom or treaty. This is an autonomous source listed in Article 38 of the Statute of the International Court of Justice, June 26, 1945, 59 Stat. 1055, 1060, T.S. No. 993. See supra note 15.

49. Declaration on Principles of International Law Concerning Friendly Relations and Cooperation Among States in Accordance with the Charter of the United Nations, G.A. Res. 2625, 25 U.N. GAOR Supp. (No. 28) at 121, U.N. Doc. A/8028 (1970).

50. G.A. Res. 3452, 30 U.N. GAOR Supp. (No. 34) at 91, U.N. Doc. A/10034 (1975).

51. Filartiga, 630 F.2d at $882-83$. The court indicated its view of the significance of this Resolution by reproducing it in its entirety in a footnote. See id. at 882 n.11.

52. Id. at 883 .

53. Filartiga, 630 F.2d at 883 (quoting E. Schwelb, Human Rights aNd the INTERNational Community 70 (1964)) (enuphasis added).

54. Id. at 883-84. The International Covenant on Civil and Political Rights, G.A. Res. 2200 (XXI)(A), 21 U.N. GAOR Supp. (No. 16) at 52, U.N. Doc. A/6316 (1966) is both a Resolution and a multilateral treaty. It entered into force as a treaty on March 23, 1976. The United States and 106 other nations voted for this Covenant as a Resolution. No country voted against the Resolution, nor did any country abstain. But sixteen countries were absent at the time of the vote, including Uganda and South Africa. See XI UNITED NAtions REsolutions 51 (D. Djonovich ed. 1975). President Carter signed the Covenant in its treaty forin in 1977, but, as of September 1983, the Senate has not ratified it. As of December 31, 1981, 69 countries had ratified the Covenant. The United States and Paraguay, the two countries of concern in the Filartiga case, were notably absent from the list of ratifying nations. See Multilateral Treaties Deposited with the Secretary-Gencral 117, U.N. Doc. ST/LEG/SER.E/1 (1982).

The Filartiga court cited two other treaties as evidence of the international consensus against torture: the American Convention on Human Rights, Nov. 22, 1969 OAS Treaty Series No. 36, - OAS OFF. REC. OEA/Ser.K/XVI/1.1, Doc. 65, Rev. 1, Corr. 1, reprinted in 9 INT'L LEGAL MATERIALS 99 (1970), and the European Convention for the Protection of Human Rights and 
ture violates international law. 55

The numerous instances in which the Filartiga court cited General Asseinbly Resolutions as authority make clear the court's implicit holding that these Resolutions constitute authoritative sources of international law. The court did not engage in any detailed historical analysis to see whether actual state practice would support the court's conclusion that torture violates international law. ${ }^{56}$ Thus, the court did not

Fundamental Freedoms, Nov. 4, 1950, 1950 European T. S. No. 5, 213 U.N.T.S. 222 (entered into force Sept. 3, 1953). In citing these treaties the court merely paraphrased the authorities cited by an international law professor whose affidavit had been used to support Filartiga's complaint. See Affidavit of Richard B. Lillich at 3, Exhibit E, Affidavit of International Law Experts, Filartiga v. Pena-Irala, 630 F.2d 876 (2d Cir. 1980)(on file in Second Circuit library).

Despite the court's reference to these treaties, the court made little pretense of resting its holding on treaty law. The court acknowledged quite early that the Filartiga family had not contended their action arose directly under a treaty of the Umited States. See Filartiga, 630 F.2d at $880 \mathrm{n} .7$ and accompanying text. Although both the United States and Paraguay have ratified the UN Charter, the Charter's statements on human rights are much too ambiguous to have supported the court's holding. Thus, by default, General Assembly Resolutions appear to be the "authoritative source" of international law on which the Filartiga court relied.

55. Filartiga, $630 \mathrm{~F} .2 \mathrm{~d}$ at $883-84$. There are two reasons, independent of the merits of the legal issues presented in the case, why the court may have held for the appellant (torture victim's family) in Filartiga. First, the egregious human rights violations may have prompted the court to take an expansive view of international law. Second, the court may have found for the appellant in this case simply because the appellee (alleged torturer) was poorly represented by counsel. Counsel for the appellee actually conceded the following point: "plaintiff' allegations that contemporary international law condemns torture, are, and remain, uncontradicted. . . . Simce the testimony in support of that allegation of fact was not clearly insubstantial, the character of the norms of contempozary international law . . . must be taken as alleged by plaintiffs." Movants' Memorandum of Law in Opposition to Motion of Amnesty International at 4-5, as quoted in Appellants Reply Brief at 2, Filartiga v. Pena-Irala, 630 F.2d 876 (2d Cir. 1980) (on file in Second Circuit library).

Counsel for the appellee chose to argue only that conduet that did not affect the relationship between states, of between an individnal and a foreign state, could not be a violation of international law. See Appellee's Brief at 11-15, Filartiga v. Pena-Irala, 630 F.2d 876 (2d Cir. 1980) (on file in Second Circuit library). The trial court dismissed the case on the basis of this argument. See Memorandum and Order at 3-4, Filartiga v. Pena-Irala, No. 79-C-917 (E.D.N.Y. May 15, 1979)(on file in Second Circuit library).

In contrast to the appellee's virtual concession on the point, the appellants had substantial support, in the form of affidavits from several law professors, for the proposition that torture constitutes a violation of international law. See, eg., Affidavit of Myres S. McDougal (the Universal Declaration of Human Rights, and the International Covenant on Civil and Political Rights both proscribe torture and have become customary international law); Affidavit of Richard B. Lillich (various resolutions, and treaties that the United States has not ratified, reflect the emergence of a norm of customary international law condemning torture); Affidavit of Richard A. Falk (a consensus of states can generate new norms of customary international law through the formal procedures of the United Nations). These affidavits are part uî Exhibit E, Affidavits of International Law Experts, Filartiga v. Pena-Irala, No. 79-C-917 (E.D.N.Y. 1979)(on file in Second Circuit library).

56. See Fulartiga, 630 F.2d at $881,884$. 
rest its decision on bona fide customary legal principles. ${ }^{57}$ Moreover, its decision could not have been based on treaty law because neither the United States nor Paraguay have ratified the treaties that the Filartiga court cited. 58

57. In fact, the court was not employing traditional custom analysis at all. Throughout its opinion, the filartiga court applied a relaxed standard for proof of customary international law, asserting that a principle must only "command the general assent of civilized nations to becoune binding." Id. at 881. The court borrowed this phrase from The Paquete Habana, 175 U.S. 677, 694 (1900), but took it out of context. In The Paquete Habana, the Supreme Court engaged in over twenty pages of analysis-spanning five centuries of history-to ascertain a principle of customary law. The Supreine Court's exhaustive analysis revealed far more than whether the principle in question commanded "the general assent of civilized nations."

The standard for custom in the International Court of Justice Statute is also much more rigorous than Filartiga's standard. The ICJ recognizes customary international law when it is "evidence of a general practice accepted as law." See Statute of the International Court of Justice, June 26, 1945, Article 38, 59 Stat. 1055, 1060, T.S. 993. This two-part test requires both the general practice of nations, which one authority says must be diuturnitas-that is, uniform behavior for soine time-as well as acceptance as law or opinio juris. See Arangio-Ruiz, The Normative Role of the General Assembly of the United Nations and the Declaration of Principles of Friendly Relations, 137 ReCUEIL DES Cours 419, 482 (1972-III); accord RESTATEMENT (REVISED) OF THE Foreign Relations LaW OF the UNITED STATES § 102(2) comments b, $c$ and reporters' note 2 (Tent. Draft No. 1, 1980).

The Filartiga court unwittingly demonstrated several times that it was not applying the same rigorous standard for ascertaining custoin that the Supreme Court and International Court of Justice would use. The Filartiga court casually brushed over the problem that although many countries condemn torture with their words, they continue to practice it with their deeds. See Filartiga; $630 \mathrm{~F} .2 \mathrm{~d}$ at $884 \mathrm{n}$.15. The court's weak explanation for this defect in its argument was that "states often violate international law, just as individuals often violate municipal law." Id. Such a comment flies in the face of fundamental requirements for proof of custom. Yet this lax attitude toward custom even appeared in the court's summary of its holding. The court said that virtually all the nations of the world had renounced torture as an instrument of official policy "in principle if not in practice." Filartiga, 630 F.2d at 880 (emphasis added). This remark bluntly contradicts the all-important requirement for customary principles of consistent practice by most, if not all, nations. The court demonstrated with this statement that it was paying attention to what nations say rather than what they $d o$. The court used similar language later in the opinion, where it said it had little difficulty discerning universal renunciation of torture in the modern usage and practice of nations. Id. at 883 .

58. See supra note 54.

Dean Rusk, former Secretary of State, described the legal arguments in the Filartiga opinion as a "gossamer web of authority." Rusk, A Comment on Filartiga v. Pena-Irala, 11 GA. J. INT'L \& Comp. L. 311,312 (1981). He added that: "The ghosts of many a coininon law judge would nod approvingly." Id. at 311 . Rusk anticipated that the Filartiga decision is "likely to find its place as a legal oddity picked up in "but see. . . footnotes by diligent scholars." Id.

The Filartiga decision prompted a flurry of legal commentary. In particular, commentators were highly critical of the court's new, expansive reading of the Alien Tort Claims Act, 28 U.S.C. $\$ 1350$ (1976), as providing federal court jurisdiction over international human rights claims. See, e.g., Judicial Decision, Jurisdiction-Alien Tort Statute-Whether Torture Constitutes a Tort in Violation of International Law, 75 AM. J. INT'L L. 149 (1981); Symposium-Federal Jurisdiction, Human Rights, and the Law of Nations: Essays on Filartiga v. Pena-Irala, 11 GA. J. INT'L \& Comp. L. 305 (1981); Blum and Steinhardt, Federal Jurisdiction Over International Human Rights Claims: The Alien Tort Claims Act After Filartiga v. Pena-Irala, 22 HARv. INT'L L.J. 53 (1981); Case Comment, Torture as a Tort in Violation of International Law, 33 STAN. L. REv. 353 (1981); 


\section{Cases Since Filartiga and Texaco Overseas.}

Since Filartiga, several courts have imphicitly adopted the Filartiga court's expansive use of General Asseinbly Resolutions as full-fledged sources of international law. ${ }^{59}$ Other courts, however, including a panel of the Court of Appeals for the Second Circuit, have ignored the Filartiga court's holding and have continued to disregard UN General Assembly Resolutions as authoritative statements of the law. ${ }^{60}$ In Fernandez $v$. Wilkinson, ${ }^{61}$ the case adopting most closely the Filartiga position, a Cuban refugee who was being held in federal prison pending deportation filed a habeas corpus claim. The federal district court made an elaborate and far-reaching argument in support of construing General Asseinbly Resolutions as sources of international law62 and used Resolutions to support its conclusion that indefinite imprisonment of a refugee violates international law. ${ }^{63}$ The Court of Appeals for the Tenth Circuit affirmed the decision, ${ }^{64}$ but it is unclear whether the Court of Appeals endorsed the district court's international law arguinents, because the appellate decision rests primarily on domestic law. ${ }^{65}$

Several other cases manifest soine support for the Filartiga position by their use of General Assembly Resolutions. ${ }^{66}$ In Jafari v. Is-

Note, Enforcement of International Human Rights in the Federal Counts After Filartiga v. PenaIrala, 67 VA. L. Rev. 1379 (1981). This note concentrates on a different aspect of the Filartiga holding: its reliance on General Assembly Resolutions as a source of international law.

59. See infra notes $61-71$ and accompanying text.

60. See infra notes $72-77$ and accompanying text.

61. 505 F. Supp. 787 (D. Kan. 1980), affd, Rodriguez-Fernandez v. Wilkinson, 654 F.2d 1382 (10th Cir. 1981).

62. See id. at 797-98.

63. Id at 798. The district court apparently believed it could play a part in advancing human rights by making international law applicable in an area-human rights-in which Congress has repeatedly declined to do so:

The United States . . . is signatory to very few international human rights agreements and ratifying state to even fewer such agreements. Moreover, a strong argument can be made that the United States does not follow even the spirit of some of the international human rights agreements to which it is a party. Instead, other concerns-economic, political, and social-assume preeminence to the detriment of human rights on an international scale.

Id at 799 (quoting Stotzsky, Book Commentary, 11 LAWYER OF THE AMERICAS 229, 240 (1979)mistakenly cited as 11 MinMI J. INT'L L.).

64. See Rodriguez-Fernandez v. Wilkinson, 654 F.2d 1382 (10th Cir. 1981).

65. The majority opinion in Wilkinson made abbreviated references to many of the same principles that the district court relied on, thus implying that the decision inay have had some basis in international law. But the dissenting judge suggested the contrary: "Like the majority of the panel, I agree that the present controversy should be resolved on the basis of domestic law, as opposed to international law, which was the basis for the trial court's release order." Wilkinson, 654 F.2d at 1390 (McWilliams, J., dissenting).

66. In Lareau v. Manson, 507 F. Supp. 1177 (D. Conn. 1980), modified on other grounds, 651 F.2d 96 (2d Cir. 1981), the court applied Standard Minimum Rules for the Treatment of Prisoners 
lamic Republic of Iran, 67 a case involving the Ayatollah Khomeini's expropriation of foreign-owned property, the court dismissed a claim brought under the Alien Tort Claims Act ${ }^{68}$ and the Foreign Sovereign Immunities Act. ${ }^{69}$ The court cited Filartiga for the proposition that a practice violates international law when it is "so universally abhorred that its prohibition commands the 'general assent of civilized nations." "70 Although the court apparently accepted Filartiga's permissive standard for ascertaining principles of international law, it dismissed the claim on the ground that "commercial violations . . . do not constitute breaches of international law."71

The strongest case opposing Filartiga's position on General Assembly Resolutions was decided by the Court of Appeals for the Second Circuit approximately one year after the Second Circuit's Filartiga 'decision. In Banco Nacional de Cuba v. Chase Manhattan Bank, ${ }^{72}$ the court decided an expropriation dispute between an American bank and the state bank of Cuba. The court considered the same General Assembly Resolutions that the Texaco Overseas arbitrator had analyzed in $1977^{73}$ but reached the opposite conclusion. The court held that the Resolutions do not correctly reflect international law because they mandate "appropriate compensation" for expropriated property whereas the United States has always advocated the standard of

developed by the United Nations Economic and Social Council under the mandate of the United Nations Charter. Citing Filartiga, the court found that the Minimum Standards,

may be significant as expressions of the obligations to the international community ... and as part of the body of international law (including customary international law) concerning human rights which has been built upon the foundation of the United Nations Charter.

Id. at 1188 n.9. The Lareas courn asserted that Filariga supported the proposition that the UN "Charter's provisions on human rights are evidence of principles of customary international law recognized as part of the law of the United States." Id at 1188.

The following year, in Jaffee v. United States, 663 F.2d 1226 (3d Cir. 1981) (en banc), cert. denied, 456 U.S. 972 (1982), a dissenting judge urged that forcing a soldier to participate in a radiation test violates the Universal Declaration of Human Rights and several other United Nations Declarations. See id. at 1249. The dissenting judge reached the inexplicable conclusion that because such conduct violated international legal principles, it also violated the Constitution and the laws of the United States.

67. 539 F. Supp. 209 (N.D. Ill. 1982).

68. 28 U.S.C. $\& 1350$ (1976).

69. 28 U.S.C. $\$ \$ 1330,1332,1391,1441,1602-1611$ (1976).

70. Jafari, 539 F. Supp. at 215.

71. Id Iromically, the court would have found that Iran lacked sovereign immunity under the Foreign Sovereign Immunities Act only if a commercial activity had been at issue. See id. at 210.

72. 658 F.2d 875 (2d Cir. 1981). None of the judges who decided Banco Nacional de Cuba y. Chase Manhattan Bank sat on the Filartiga panel.

73. See supra note 37. 
"prompt, adequate and effective compensation."74 The court engaged in conventional custom analysis to reach this result, notimg that General Assembly Resolutions "are of considerable interest" but that they "do not have the force of law."75 It observed that "the actions of members of the General Assembly [present] at best a confused and confusing picture as to what the consensus may be as to the responsibilities of an expropriating nation to pay 'appropriate compensation." "76 The court added that "[t]he resolutions, the views of commentators, and the positions taken by imdividual states or blocs are varied, diverse, and not easily reconciled."77

\section{The Argument for Using General Assembly Resolutions as a SOURCE OF INTERnational LAW}

The suggestion that UN Gèneral Assembly Resolutions should serve as an authoritative source of international law originated almost exclusively with legal scholars. The arguments in favor of Resolutions serving as an authoritative source of law can be roughly divided into three categories.

First, some scholars assert that because General Assembly Resolutions derive their authority from the UN Charter-a treaty bimding on all UN members-any Resolution concerning subjects addressed by the Charter has the authority of the Charter itself. The UN Charter

74. Banco Nacional, 658 F.2d at 889, 891. The court held that the General Assembly's term "appropriate compensation" must be construed to mean "full compensation" because the United States delegation consistently favored the latter standard.

75. Id. at 889.

76. Id at 891 .

77. Id

Several other recent cases also follow the traditional doctrine and reject General Assembly Resolutions as authoritative legal sources. In Hanoch Tel-Oren v. Libyan Arab Republic, 517 F. Supp. 542 (D.D.C. 1981), a case involving a terrorist bombing, the court could have cited a variety of General Ascembly Resolutions to establish a violation of international law, such as Universal Declaration of Human Rights, art. 3, G.A. Res. 217 (III), 3 U.N. GAOR, U.N. Doc. A/777 (1948) (guarantees all persons the right to life, liberty and security). Instead, the court distinguished Filartiga and held that it lacked jurisdiction because there was no violation of international law. Hanoch Tel-Oren, 517 F. Snpp. at 549. The court added that "to interpret international human rights law to create a federal private right of action overstates the level of agreenent among nations on remedies for human rights violations.' " Id. at 549 (quoting Note, Torture as a Torl in Violation of International Law: Filartiga v. Pena-Irala, 33 STAN. L. Rev. 353, 357 (1981)).

In Centre for the Independence of Judges and Lawyers of the United States, Inc. v. Mabey, 19 Bankr. 635 (D. Utah 1982), the court rejected the novel argument that a bankruptcy judge violated international law when he failed to recuse himself from cases in which he had a possible conflict of interest. Responding to plaintiff's citation of a number of General Assembly Resolutions and similar international authorities, id at 646, the court stated that "[u]nless or until ratified as treaties, those documents at best serve as evidence of international 'common law,' or customary law." Id. at 647 (emphasis added). 
addresses many topics other than organizational details for the various bodies comprising the UN. These topics include self-determination, equal rights, human rights and fundamental freedoms, and economic cooperation. ${ }^{78}$ Thus, the first approach grants the General Assembly broad powers. Jorge Castaneda, a Mexican diplomat, has argued that because there is no body competent to judge the scope of the General Assembly's authority other than the Assembly itself, the General Asseinbly's powers can evolve organically to ineet new circumstances. ${ }^{79}$ Thus, through its repeated efforts to declare principles of international law that concern subjects discussed in the UN Charter, the General Assembly may have secured additional powers beyond the recounmendatory powers listed in the UN Charter. ${ }^{80}$ This view has also appealed to some Soviet scholars, although they distinguish between "binding rules of law" and "sources" and call Resolutions the forner. ${ }^{81}$

A second group of scholars suggests that General Assembly Resolutions can replace certain elements needed to prove custom or serve.as a substitute for any extrinsic proof of custom. Three law professors filed affidavits in the Filartiga case consistent with this view. ${ }^{82}$ Professor Myres McDougal argued that the Universal Declaration of Human Rights and associated covenants on human rights have "become cus-

78. See, e.g., U.N. CHARTER art. 55, 56, 73.

79. See J. Castaneda, Legal Effects of United Nations Resolutions 15-16 (1969); see also R. Higons supra note 20, at 118-19; Schachter, The Relation of Law, Politics and Action in the United Nations, 109 RECUEIL DES Cours 186 (1963-11).

Schachter reveais a fiaw in Castaneda's argument. The San Francisco Conference said that if an interpretation of the Charter is not generally acceptable, it will be without binding force. See id. at $186 \mathrm{n}$.4. In discerning whether a Resolution is generally acceptable a court has two choices. First, it could look at which countries voted for the Resolution and infer consensus from that. But that would be circular-every Resolution that passed the General Asseinbly would be "generally acceptable," and the qualification made at the San Francisco conference would be reduced to mere surplusage. Alternatively, a court could investigate both the general practice and the pronouncements of nations. But this analysis inerely repeats the analysis used to determine whether an international custom exists. If a court must first apply the "custon analysis" to verify that the Resolution is "generally acceptable," it is misleading to declare the Resolution an authoritative statement of the law. Accord G.I. TUNKIN, TheORY OF INTERNATIONAI LAW 171-73 (1974); Schwebel, The Effects of Resolutions of the U.N. General Assembly on Customary International Law, 73 PROC. OF THE AM. SOC'Y OF INT'L L. 303-05 (1979). Some housekeeping Resolutions dealing with internal UN affairs, however, do have a binding effect under the Charter. See U.N. Charter art. 15-22; J. Castaneda, Legal Effects of United Nations Resolutions 23 (1969) (four-fifths of General Assembly Resolutions are housekeeping Resolutions).

80. Cf. Wilner, Filartiga v. Pena-Irala : Comments on Sources of Human Rights Law and Means of Redress for Violations of Human Rights, 11 GA. J. INT'L \& CoMP. L. 317, 321-22 (1981) (emphasizing possible value of universal international legislative organ).

81. See Osakwe, Consemporary Soviet Doctrine on the Sources of General International Law, 73 PROC. OF THE AM. SOC'Y OF INT'L L. 310, 320 (1979).

82. These affidavits are part of Exhibit E, Affidavits of International Law Experts, Filartiga v. Pena-Irala, No. 79-C.917 (E.D.N.Y. 1979). 
tomary international law and thus a part of the Law of Nations." 83 Professor Richard Lillich argued that Resolutions can reflect the emergence of a customary norm, ${ }^{84}$ and Professor Richard Falk asserted that a consensus of states can generate new norms of customary imternational law through the formal procedures of the United Nations. ${ }^{85}$ Some scholars have even gone so far as to speak of "instant custom," resulting from UN action. ${ }^{86}$ It is arguable that this group of scholars would only incorporate Resolutions into the existing source of custom, but the practical effect would nonetheless be to treat General Assembly Resolutions as a separate authoritative source.

Proponents of the third approach argue that General Assembly Resolutions have inherent authority as normative standards adopted by an international body speaking for all of its members. These arguments vary considerably. Some argue that a nation's declarations to the international community create an expectation that the state will' adhere to the primciples it declares. ${ }^{87}$ Proponents of this argument would probably contend that if nations create such expectations, it is not unreasonable to treat their statements as law. A group of Soviet scholars has suggested that when Resolutions are consistent with $j u s$ cogens (peremptory norms) the Resolutions can serve as sources of international law. ${ }^{88}$ Still other commentators would defer to the "international rules of the road" established by the General Assembly whenever states use language of firm obligation in UN Resolutions or Declarations because such language indicates that states intend to assert binding rules of law.89

\section{ARguments Against Use of Resolutions as A SOURCE OF LAW}

Despite scholars' suggestions that the General Assembly can now play a direct role in the formation of international law, United States courts should continue to refrain from treating General Assembly Res-

83. See Affidavit of Myres S. McDougal, included in Exhibit E, supra note 55 (referring to his book HUMan RIGHTS AND WORID PUBLIC ORDER (1980)).

84. See Affidavit of Richard B. Lillich at 4, included in Exhibit E, supra note 55.

85. See Affidavit of Richard Anderson Falk at 2, included in Exhibit E, supra note 55.

86. See, e.g., Joyner, U.N. General Assembly Resolutions and International Law: Rethinking the Contemporary Dynamics of Norm-Creation, 11 CAL. W.L. REV. 445, 458 (1981).

87. See, e.g., Note, Toward an Intemational Law of Human Rights Based Upon the Mutual Expectations of States, 2I VA. J. INT'L L. 185, 205 (1980).

88. See Osakwe, Contemporary Soviet Doctrine on the Sources of General International Law, 73 PROC. OF THE AM. SOC'Y OF INT'L L. 310, 321 (1979).

89. See Rosenstock, The Declaration of Principles of International Law Concerning Friendly Relations: A Survey, 65 AM. J. INT'L L. 713, 715-16 (1971). 
olutions as authoritative sources of international law.90 First, General Assembly Resolutions are inadequate as legal sources because they frequently contradict each other or are too vaguely stated to be applied as law. For example, United Nations General Assenubly Resolution 1803 (XV1I) of December 14, 1962, authorizes states to nationalize, expropriate or requisition property and override private interests for the sake of the public interest.91 Yet the Universal Declaration of Human Rights (Article 17) provides that no one shall be arbitrarily deprived of his property. ${ }^{92}$ The legal rules that could be derived from these two Resolutions, if read together, would reflect the predisposition of the interpreting court at least as nucli as the intention of the General Assembly.

Consider the Filartiga problem in this light. A General Assenibly Resolution declares that acts of torture or other cruel, inhuman, or degrading treatment or punishment are an offense to human dignity and should be condemned. ${ }^{93}$ In a case in whicli the alleged torture is not as egregious as it was in Filartiga, how is a United States court going to determine whether certain activity falls within this proscription? In other circumstances, would the British treatment of imprisoned mem-

90. Many scholars also advocate this view. For example, Georg Schwarzenberger rejected General Assembly Resolutions as authoritative legal sources in his MANUAL OF INTERNATIONAL LAw:

The General Assembly has the right to discuss any matter within its jurisdiction. Save in relation to disputes or situations of which the Security Council is seized, the General Assembly may also make recommendations .... Whatever political or moral force such recommendations of the General Assembly may claim, they are not legally binding.

G. Schwarzenberger \& E. Brown, A Manual of International Law 233 (6th ed. 1976) (emphasis in original); accord Virally, The Sources of International Law in Manual of Public INTERNATIONAL LAW 162 (M. Sorensen ed. 1968).

Many prominent legal scholars adhere to this view. See, e.g., R. HIGGINS, THE DEVELOPMENt of International Law Through the Political Organs of the United Nations 5 (1963) (Resolutions are not per se binding although they may embody rules which are binding, with or without the help of the Resolution); G. TUNKIN, THEORY OF INTERNATIONAL LAw 173 (1974) (Resolutions are recommendations and do not impose legal obligations on UN members); Schachter, The Evolving Intemational Law of Development, 15 Colum. J. TransNat'L L. 1, 4 (1976)(virtually all governments have affirmed the general proposition that General Asseunbly Resolutions are not legally binding except, of course, on internal UN matters); Schwebel, The Effect of Resolutions of the U.N. General Assembly on Customary International Law, 73 PROC. OF THE AM. SOC'Y OF INT'L L. 301 (1979)(General Assembly lacks legislative powers-Resolutions are not binding on meinber states or in international law at large).

91. See Permanent Sovereignty Over Natural Resources, G.A. Res. I803 (XVII), 17 U.N. GAOR Supp. (No. 17) at 15, U.N. Doc. A/5217 (1962).

92. See Universal Declaration of Human Rights, G.A. Res. 217 (II1), 3 U.N. GAOR, U.N. Doc. 1/777 (1948).

Sir Gerald Fitzmaurice highlighted this contradiction between Resolution 1803 and Resolution 217 in Fitzmaurice, The Future of Public International Law and of the Intemational Legal System in the Circumstances of Today, LIVRE du CENTENAIRE, 1873-1973 196, 229-30 (1973).

93. See Declaration on the Protection of All Persons Froun Being Subjected to Torture, G.A. Res. 3452, art. 2, 30 U.N. GAOR Supp. (No. 34) at 91, U.N. Doc. A/10034 (1975). 
bers of the Irish Republican Army qualify as torture by UN standards? Would capital punishment in the United States be proscribed by this language? The language of the Resolution, taken in isolation, cannot provide an answer without reference to other sources of international law.

Second, and inost importantly, General Assembly Resolutions are unreliable indicators of world opinion. When courts use General Assembly Resolutions as authoritative sources of international law, they undermine the rigorous requirements of custom by accepting in place of these requirements a lax standard for proof of legal principles. In effect, courts eliminate the requirement of actual state practice and instead accept weaker proof that states have intended a given principle to be legally binding.

Although under some circumstances General Assembly Resolutions accurately reflect international law, often they do not. ${ }^{94}$ Some: Resolutions receive a unanimous vote, some are adopted without any vote, and others are passed by an overwhelming margin but not supported by certain blocs of countries. A court might devise an elaborate formula for determining which Resolutions are sufficiently credible to serve as sources of bimding international law. But to do so conscientiously it would repeat much of the analysis used to determine whether a principle qualifies as international custom. ${ }^{95}$ Thus, use of Resolu-

94. Arangio-Ruiz describes how law can carelessly emerge from the General Assembly:

As everybody in the United Nations is convinced that recommendations are per se not mandatory, States tend to embellish their image by putting forward draft resolutions. Other States tend naturally to support such drafts. And potential or natural opponents are often reluctant to face the risk of tamishing or spoiling their own image by opposing the proposal openly or by casting a negative vote.

Arangio-Ruiz, The Normative Role of the General Assembly of the United Nations and the Declarations of Principles of Friendly Relations, 137 RECUEIL DES CouRs 419, 457 (1972-111). Garibaldi called this "fake agreement." Garibaldi, The Legal Status of General Assembly Resolutions: Some Conceptual Observations, 73 Proc. OF THE AM. SOC'Y OF INT'L L. 324, 326 (1979).

95. Consider, for example, a Umited States court trying to decide whether international law forbids a country from claiming exclusive rights to mine a certain section of the deep sea-bed. In 1968, the United Nations General Assenbly adopled Resolution 2467 (XXIII), titled "Examination of the question of the reservation exclusively for peaceful purposes of the sea-bed and the ocean floor, and the subsoil thereof, underlying the high seas beyond the limits of present national jurisdiction, and the use of their resources in the interests of mankind." 23 U.N. GAOR Supp. (No. 18), U.N. Doc. A/7218 (1968). One hundred and twelve nations, including the United States, out of 119, voted for provision (A) of this Resolution which states: "The General Assembly [is] convinced that such exploitation should be carried out for the benefit of mankind as a whole, irrespective of the geographical location of States, taking into account the special interests and needs of the developing countries." XII UNITED NATIONS Resolutions 66, 129 (D. Djonovich ed. 1975).

There is simply no way to tell from the text of the Resolution and the split voting record on various other clauses of the Resolution dealing with marine pollution, id. at 130, and the use of "international machinery" to promote exploitation of sea-bed resources, id. at 67,130 , whether the 
tions as sources of international law is not faithful to the original concern of nations in developing international law that as sovereign nations they cannot be bound without their consent. 96

In Texaco Overseas ${ }^{97}$ the arbitrator ascertained a dramatically different legal rule because he used General Assembly Resolutions, instead of custoin, as a source of international law. In Texaco Overseas the arbitrator used General Asseinbly Resolutions as a shortcut to ascertaining the international legal standard for reimbursement following expropriation of foreign assets. Instead of analyzing past state practice

"exploitation for the benefit of mankind" principle reflects current international law. Provision (A) suggests that minung countries must take into account the needs of developing countries, a principle which seems to be at odds with exclusive rights. Without the familiar tools used to ascertain customary international law there is simply no way to know which principle accurately reflects the law on this subject.

In fact, recent developments suggest that this Resolution may not express the current view. The United States has chosen not to sign the Third Law of the Sea Treaty, which might have governed the situation, precisely because its provisions on sea-bed mining reflected the same concerns as the General Assembly Resolution. See New York Times, Dec. 11, 1982, at 1, col. 2. Thus a court would not discover that this Resolution, which commanded widespread support at the time of passage, may be contrary to custom until it engages in the custom analysis.

96. Multilateral treaties that set forth legal principles are the safest nuechanism for avoiding affronts to sovereignty. Most multilateral treaties originate in the United Nations. Many are the result of work by the U.N. International Law Commission: The Restatement uses this method as one illustration of how international law is formed. See RESTATEMENT (SECOND) Of THE FOREIGN RELATIONS LAW OF THE UNITED STATES \& 1 comment d, illustration 2 (1962) (International Law Commission refers draft convention to the General Assembly; General Assembly recommends adoption and convenes a conference of states to sign and ratify the convention).

Unlike General Assembly Resolutions, multilateral treaties are meant to be binding. Each country that joins a treaty accepts that binding obligation when it joins the treaty. As a result, the codification of international law through the vehicle of treaties has been a slow process. Consider, for example, how long it has taken for the International Law Commission to develop the Vienna Convention on the Law of Treaties, May 23, 1969, U.N. Doc. A/CONF.39/27. The Commission started work in 1949 and eventually produced a draft convention in 1969 . The treaty entered into force on January 27, 1980. The Umited States still has not ratified the treaty. See Multilateral Treaties Deposited with the Secretary-General 619, U.N. Doc. ST/LEG/SER.E/1 (1982).

Multilateral treaties have met with substantial success on some issues such as the law governing treaty obligations and the use of outer space. See Vienna Convention on the Law of Treaties May 23, 1969, U.N. Doc. A/CONF. 39/27, (1969), 63 AM. J. of INT'L L. 875 (1969) (entered into force January 27,: 1980); Treaty on Principles Governing the Activities of States in the Exploration and Use of Outer Space, Including the Moon and Other Celestial Bodies, January 27, 1967, 18 U.S.T. 2410, T.I.A.S. No. 6347, 610 U.N.T.S. 205 (entered into force October 10, 1967). Multilateral treaties have met with some setbacks on other more controversial issues, such as the Law of the Sea. The Third Law of the Sea Treaty was signed by 117 nations in December 1982 . The United States did not sign it because it objects to certain sea-bed mining provisions. See New York Times, Dec. 11, 1982, at 1, col. 2. On extremely controversial issues such as human rights and redistribution of economic wealth, multilateral treaties may not even be a viable option. See International Covenant on Civil and Political Rights, Annex to G.A. Res. 2200 (XXI), 21 U.N. GAOR Supp. (No. 16) at S2, U.N. Doc. A/6316 (1966); International Covenant on Economic, Social and Cultural Rights, id at 49 . The United States Congress has never ratified either of these treaties.

97. 17 INT'L Legal Materials 1 (1978). 
in expropriation disputes, the arbitrator analyzed the voting patterns for various Resolutions. ${ }^{98}$ The arbitrator concluded that one Resolution that nandated "appropriate compensation" reflected the law because the Resolution appeared to have garnered support from all the najor blocs of nations. ${ }^{99}$ Yet when a Umited States court einployed the rigorous requirements of custom analysis in considering the same question a few years later in Banco Nacional de Cuba v. Chase Manhattan $B a n k,{ }^{100}$ it found no consensus on what should be the proper standard for reimbursement following expropriation. ${ }^{101}$

The Filartiga court, like the Texaco Overseas arbitrator, used General Assembly Resolutions as a shortcut to establishing principles of international law. ${ }^{102}$ This method of analysis fails to consider the sovereignty of individual states. If General Asseinbly Resolutions can be considered law even though they do not meet the rigorous standards for custom, then there is a risk of binding a state to principles that it has never accepted as law. A United States court should not treat General Asseinbly Resolutions as an authoritative legal source without employing the traditional method for determining whether international custom exists and looking for a willingness on the part of each nation to be bound. Many UN member nations would not consent to be bound by the legal principles embodied in certain Resolutions even if the Resolutions were adopted by a majority or unanimous vote. ${ }^{103}$

Some observers have suggested that United States courts could regard as bimding any Resolution for which the United States voted. They suggest that the United States delegation would vote carefully if courts accorded such weight to its vote. Yet even this stipulation would not serve as a sufficient safeguard. The United States sometimes votes for Resolutions to win favor with its Third World allies even though

98. Id at 28. The Texaco Overseas arbitrator provided some explanation of his methodology. He said,

it appears essential to this Tribunal to distinguish between those provisions lof Resolutions] stating the existence of a right on which the generality of the States has expressed agreement and those provisions introducing new principles which were rejected by certain representative groups of States and having nothing more than a de lege ferendo value only in the eyes of the States which have adopted them; as far as the others are concerned, the rejection of these same principles implies that they consider them as being contra legem.

99. Id at 30.

100. 658 F.2d 875 (2d Cir. 1981).

101. Id at $891-92$.

102. See supra notes $42-58$ and accompanying text.

103. Accord Rusk, A Comment on Filartiga v. Pena-Irala, 11 GA. J. INT'L \& CoMP. L. 311,315 (1981) ("There are members who simply would not submit to a fundamental change in the role of the General Assembly by stealth."). 
the Resolutions reflect views contrary to United States interests. ${ }^{104}$ Thus, even if only unanimous Resolutions are accepted as law, there is a potential for abuse. ${ }^{105}$ One author calls this "fake consensus." 106

The Banco Nacional case illustrates the kind of situation in which a United States court would not want to be bound by the United Nations General Assembly's determination of international law. The General Assembly's standard for compensation following expropriation would have entailed substantial losses for American investors who held assets in pre-Castro Cuba. ${ }^{107}$

The Cuban state bank argued in Banco Nacional that the court should follow General Assembly Resolution 1803 (XVII), a Resolution that mandated "appropriate compensation" following expropriation. ${ }^{108}$ The. United States had opposed this provision and advocated an alternative standard of "prompt, adequate and effective" compensation. ${ }^{109}$ But the United States ultimately voted in favor of Resolution 1803 in a spirit of compromise. ${ }^{110}$ The Banco Nacional de Cuba court did not treat the Resolution as an authoritative statement of the law because the court recognized that the inajority vote in favor of Resolution 1803 masked considerable discord over what the precise legal standard

104. Frequently, the United States representative to the United Nations casts his vote to accommodate other nations rather than to manifest a wholehearted United States endorsement of the measure. The Deputy Legal Adviser to the State Department has candidly described this practice:

[Members of the UN] often vote casually: their delegates may be instructed or loosely instructed; they may vote because the members of their group have decided or are disposed so to vote rather than because the immediate interests or considered views of their government so suggest. The members of the General Assembly typically vote in response to political not legal considerations. They do not conceive of themselves as creating or changing international law. It normally is not their intention to affect international law but to make the point which the resolution makes. The issue often is one of image rather than intemational law: states will vote a given way repeatedly not because they consider that their reiterated votes are evidence of a practice accepted as law but because it is politically unpopular to vote otherwise.

Schwebel, supra note 20, at 302. From this description of UN practice, Schwebel concludes that: "states often don't meaningfully support what a resolution says and they almost always do not mean that the resolution is law. This may be as true or truer in the case of unanimously adopted resolutions as in the case of majority-adopted resolutions. It may be truer still of resolutions adopted by "consensus." " Id; $q f$. RESTATEMENT (ReViseD) OF THE FOREIGN RELATIONS LAW OF THE UNITED STATES, Introductory Note at 15 (Tent. Draft No. 1, 1980) (consensus votes discourage dissent and put pressure on dissident states to acquiesce).

105. See Summary of Discussion; 73 PROc. OF THE AM. SOc'Y OF INT'L L. 327, 332 (1979)(comments by State Dept. representative Scliwebel on how casually countries vote in the United Nations General Assembly).

106. Schwebel, The Effect of Resolutions of the U.N. General Assembly on Customary Internaiional Law, 73 PROC. OF THE AM. SOC'Y OF INT'L L. 301,308 (1979).

107. See Banco Nacional, 658 F.2d at 892 .

108. See id

109. See id. at 888-89.

110. See id at 890 . 
should be.111 Yet if a court looked only to the voting pattern in the United Nations, as did the Texaco Overseas arbitrator, it would never get beyond the Resolution to see what nations actually believed when their economic interests were at stake.

This caveat applies with even greater force to Resolutions that did not secure a unanimous or near-unanimous vote. The so-called Group of 77 developing countries, which now numbers approximately 120 countries out of 154,112 is able to garner a two-thirds votc on a "lawdeclaring" Resolution without much difficulty. Thus, many Resolutions command an overwhelming inajority in the Umited Nations even though they lack the support of any industrialized nations. ${ }^{113} \mathrm{Al}-$ though a system under which General Assenibly Resolutions are authoritative legal sources would ensure that developing countries participated in the formulation of international law, ${ }^{114}$ there is a substantial risk that developing countries could use the process to impose their economic and political interests on nations such as the United States.

The nations of the world have not yet reached the point where they will entrust their legal rights to an assembly founded on the onenation, one-vote principle. ${ }^{115}$ Until nations expressly agree to give the General Assembly more than mere recommendatory powcrs, United States courts should refrain from attributing special authority to General Assembly Resolutions. ${ }^{116}$

\section{Conclusion}

For the time being, United States courts should continue to refuse to treat General Asseinbly Resolutions as authoritative sources of international law. This is not because the traditional sources are superior in

111. See id. at 890.

112. See Joyner, U.N. General Assembly Resolutions and International Law: Rethinking the Contemporary Dymamics of Norm-Creation, 11 CAL. W.L. REv. 445, 445 (1981).

113. Professor Rusk commented on this prospect as follows: "Nations representing less than ten percent of the world's population can now cast a two-thirds vote in the General Assembly." See Rusk, supra note 103, at 315.

114. See L. Henkin, P. Pugh, O. Schachter \& H. Smit, International Law, Cases and MATERIAis 691-92 (1980) (comments of Messrs. Nervo and Tunkin regarding desirability of developing countries' future participation in formulation and codification of international law).

115. This generalization about one-nation, one-vote ignores the substantial voting bloc of Soviet-controlled states.

116. Sir Gerald Fitzmaurice expressed disdain for the present situation in which "Assembly resolutions do not constitute law, but legal ideas are stretched and legal primciple itself warped in the vain endeavour to make them appear [as law]." Fitzmaurice, The Fufure of Public Interna. tional Law and of the International Legal System in the Circumstances of Today, LIVRE DU CentenaiRe, 1873-1973 196, 275 (1973). He added: "It is not by such means that the 'mirage' will be given genuine substance, but by a much more painful discipline." Id 
every respect. They are not. Instead, it is because General Assembly Resolutions remain too unreliable to regard as definitive sources. The Unted Nations General Assembly has remained a political body endowed with the advantages of open and uninhibited discussion. It serves a valuable function as a forum for the expression of momentary indignation and deeply held sentiments. But its strengths as an international political body are also its weaknesses as a legislative body. If member nations knew they would be bound by their votes, many Resolutions would never be passed, and the General Assembly's unique function as the voice of world opinion would be undermined.

Without General Assembly Resolutions as authoritative sources, principles of international law will continue to be difficult to ascertain. The four traditional sources of international law require more than casual examination before they will yield principles on which to found an adjudication of rights. Judicial decisions on international law are infrequent. Writings of publicists on most issues rarely suggest a uniform result. Principles of custoinary international law depend on the annorphous variables of each nation's practice and the world community's acceptance as law of a given primciple. General Assembly Resolutions can contribute to a determination of a particular custom as long as these Resolutions are considered evidence, and not complete proof, of the primciples they support. ${ }^{117}$

Gregory J. Kerwin

117. An expansive view of the sources of international law may "seem handy, when a specific poimt we want to make finds support in a General Asseinbly resolution, but we may find that after using his services it may be impossible - and intellectually dishonest-to put the genie back into the bottle." Garibaldi, The Legal Status of General Assembly Resolutions: Some Conceptual Observations, 73 PROC. OF THE AM. SOC'Y OF INT'L LAW 324, 325-26 (1979). 